\title{
Effects of Gamma Radiation Exposure to Reduce of Monocyte Count and Serum Level of IFN-Y in Industrial Radiography Workers \\ by Niken Sekarningrum
}

Submission date: 02-Sep-2020 12:53PM (UTC+0800)

Submission ID: 1378058334

File name: 9.pdf (722.75K)

Word count: 2822

Character count: 15616 


\title{
Effects of Gamma Radiation Exposure to Reduce of Monocyte Count and Serum Level of IFN- $\gamma$ in Industrial Radiography Workers
}

\author{
${ }^{1}$ Niken Sekarningrum, ${ }^{2}$ Soedjajadi Keman, ${ }^{3}$ R Azizah \\ ${ }^{1}$ Master Program Study, Environmental Health Department, Public Health Faculty \\ Airlangga University, Surabaya, Indonesia \\ ${ }^{2,3}$ Environmental Health Department, Public Health Faculty, Airlangga University, Surabaya, Indonesia \\ Email: nikensekar.ningrum@yahoo.co.id
}

\begin{abstract}
S :
Gamma radiation exposure is induce immunosuppresive against the immune system. The aim of this study was to analyze the effects of gamma radiation exposure to reduction monocyte count and serum level of IFN- $\gamma$ in industrial radiography workers. The method of the study was an observational research with longitudinal study design. Eleven industrial radiography workers were included in this study. Gamma radiation exposure was measured by using Pocket Gamma Dosimeter. Laboratory tested for monocyte count were using Differential Cell Count method and serum level of IFN- $\gamma$ was using ELISA method. The result showed that gamma radiation exposure was not exceed dose limited value (NBD) PerkaBAPETEN No. 4 Year 2013 the mean dose was $0,0088500 \mathrm{mSv}$. There was no difference among lymphocyte monocyte count (t-value $=0,811$ ) and serum level of IFN- $\gamma$ (t-value $=0,286$ ) in industrial radiography workers before and after working NDT activities. Characteristics of respondents significantly influence to decreased these dependent variables were history of the disease (infection), nutritional status, and duration of exposure. It is concluded that gamma radiation exposure decrease of monocyte count but not significantly influence to decrease of serum level of IFN- $\gamma$. It is suggested to increase partisipation for refresh training, more improving health's workers through consuming of nutritious food (more low purine and fat) and water, doing sport regularly, and also doing enough rest.
\end{abstract}

KEY WORDS : Industrial Radiography, Gamma Radiation, Monocytes,IFN- $\gamma$

\section{INTRODUCTION}

Human's desire to have a prosperous, happy, peacefull, and peace in life is realized through of developing of science and technology. One of its effeorts is use of radiation. Uses of radiation can be applied in various activities, such as : energy, industry, medicine, agriculture, archeology, and others ${ }^{[18]}$. Industrial radiography is utilization of radioactive sources or called radioisotope. Radioisotope can be used for industrial radiography techniques, gauging techniques, tracer (tracing) techniques, and electron activation analysis techniques.

Definition radiation based on Peraturan Pemerintah Republik Indonesia No. 33 Tahun $2007^{[8]}$ are :

"Radiasi adalah gelombang electromagnetik dan partikel bermuatan yang karena energi yang dimilikinya mampu mengionisasi media yang dilaluinya"

Industrial radiography activities aimed to investigate the inside of an observed object, such as testing the quality of welding's connection. Industrial radiography are applied to development of high technologies industries and has been used as one of the requirements achieve quality production. Industrial radiography including Non Destructive Test (NDT) activities with sources of gamma radiation, such as : Iridium-192 (Ir-192), Cobalt-60 (Co-60), and Selenium-75 (Se-75) which contained within device gamma camera. Development of industrial radiography technology, prior using X-ray radiation, but generally at now have switched using gamma radiation because the device are easy to use and does not require a power source.

Gamma radiation impact to human health, specially radiographer and population around the activities. Radiation is also one aspects of the physical pollution that can damage of human health and other living creatures ${ }^{[18]}$. Uses of radiation can cause negative effects on the biological aspects, such as : somatic, genetic, and stocastic effects ${ }^{[10]}$.

Data from United State Energy Atomic Commision (USEAC) reported in 1960-1968 that 152 cases accident work, including 59 cases caused by the use of radiography. The cause of the accident are : operator error (68\%), procedural error (8\%), equipment damaged $(15 \%)$, and others $(9 \%)^{[7]}$.

Blood cells have different radiosensitivities. Leucocytes are cells that have a high radiosensitivities, particularly lymphocytes. In addition, platelets also be decreased after radiation a few days to weeks then eritrocytes until a few weeks later. Therefore, a decrease lymphocyte cell count can be used to estimate the severity of which may occur as a result of acute radiation exposure in radiation workers ${ }^{[16]}$

Ionizing radiation rated reduced immune system ${ }^{[17]}$. The body which exposed by radiation may result in inhibition of cell growth and proliferation entirely immune system ${ }^{[2]}$. Gamma radiation exposure is induce immunosuppresive and play a role in 


\section{DOI: $10.18535 / \mathrm{ijsrm} / \mathrm{v} 4 \mathrm{i} 8.08$}

imbalance of cytokine expression of $\mathrm{T}$ helper (Th)1 and Th2 ${ }^{[6]}$. Th cell number can be decreased $60 \%$ compared with control group after being exposed to radiation at a dose $4 \mathrm{~Sv}{ }^{[1]}$. The negative impact in immune response suppresion will cause susceptible to infection including and increased risk of cancer induction ${ }^{[1]}$.

Gamma radiation to whole body irradiation with a low dose $40 \mathrm{mSv}$ (miliSievert) and dose rate $0,052 \mathrm{mSv} / \mathrm{h}$ in 24 hours for 5 days trial, showed changes in level of IFN- $\gamma$ (gamma Interferon) ${ }^{[12]}$. Gamma radiation exposure also causes a decrease in gene expression mesenggger Ribonucleic Acid (mRNA) IFN- $\gamma$ after 3 hours but reverse to increases mRNA expression of Interleukin- 4 (IL-4), IL-5, IL-10, and TNF- $\alpha$ (Tumor Necrosis Factor-alpha) ${ }^{[5]}$.

Statistical analysis of the limitations of epidemiology between the dose-response received by workers and the mechanism of radiation exposure on the health process requires for improvement in futher understanding. Therefore, scientific research on understanding the health effects has been made a priority for 2009-2013 by UNSCEAR at the 65th session. Research is needed more emphasis on the health effects of low-dose radiation exposure to workers against the risk of cancer and genetic effects ${ }^{[17]}$.

\section{METHODS}

The method of this study was an observational research with longitudinal study design. Eleven industrial radiography workers were included in this study Radiografer Level (RT) I, RT II, and Radiation Protection Officer (PPR) with inclusive criteria male, willing became respondents, and did not have a history of anemia. Laboratory tested for monocyte count were using Differential Cell Count method and serum level of IFN- $\gamma$ was using ELISA method.

\section{RESULT}

Characteristics of respondents in industrial radiography workers can be seen in Table 1.

Tabel 1. Characteristics of Respondents

\begin{tabular}{|c|c|c|}
\hline Characteristics of Respondents & $\mathbf{n}$ & $\%$ \\
\hline Age & & \\
\hline $20-25$ & 2 & 18,18 \\
\hline $26-30$ & 4 & 36,36 \\
\hline $31-35$ & 1 & 9,09 \\
\hline $36-40$ & 3 & 27,27 \\
\hline$>40$ & 1 & 9,09 \\
\hline Mean \pm SD & \multicolumn{2}{|c|}{$30,45 \pm 7,50$} \\
\hline \multirow[t]{3}{*}{$\begin{array}{l}\text { History of the Disease (Infection) } \\
\text { Have } \\
\text { Didn't have }\end{array}$} & & \\
\hline & 6 & 54,55 \\
\hline & 5 & 45,45 \\
\hline Mean \pm SD & \multicolumn{2}{|c|}{$1,45 \pm 0,55$} \\
\hline \multirow[t]{3}{*}{$\begin{array}{l}\text { Knowledge of Radiation Protection } \\
\text { Good } \\
\text { Poor }\end{array}$} & & \\
\hline & 11 & 100 \\
\hline & 0 & 0 \\
\hline Mean \pm SD & \multicolumn{2}{|c|}{$620,73 \pm 26,94$} \\
\hline \multicolumn{3}{|l|}{ Nutritional Status } \\
\hline Normal & 0 & 0 \\
\hline Overweight & 4 & 36,36 \\
\hline Obese & 2 & 18,18 \\
\hline Severely Obese & 5 & 45,46 \\
\hline & 0 & 0 \\
\hline Mean \pm SD & \multicolumn{2}{|c|}{$23,50 \pm 2,75$} \\
\hline \multirow{3}{*}{$\begin{array}{l}\text { Duration of Exposure } \\
\quad<8 \text { hours } \\
\geq 8 \text { hours }\end{array}$} & & \\
\hline & 9 & 81,82 \\
\hline & 2 & 18,18 \\
\hline Mean \pm SD & \multicolumn{2}{|c|}{$8,09 \pm 1,30$} \\
\hline \\
\hline$\geq 5$ years & 9 & 81,82 \\
\hline & 2 & 18,18 \\
\hline Mean \pm SD & \multicolumn{2}{|c|}{$3,91 \pm 2,47$} \\
\hline
\end{tabular}

\footnotetext{
${ }^{1}$ Niken Sekarningrum, Volume 4 Issue 08 August 2016 [www.ijsrm.in]
} 


\section{DOI: $10.18535 / \mathrm{ijsrm} / \mathrm{v} 4 \mathrm{i} 8.08$}

Path analysis was showed that characteristics of respondents significantly influence to decreased these dependent variables were history of the disease (t-value -2,35), nutritional status (t-value 1,97), and duration of exposure (t-value 2,62 ).

Gamma radiation esposure measured by personal effective dose of industrial radiography using Pocket Gamma Dosimeter. Dose measurement results can be seen in Table 2.

Tabel 2. Personal Dose in Industrial Radiography Workers

\begin{tabular}{|c|c|c|}
\hline \multirow{2}{*}{$\begin{array}{c}\text { Gamma Radiation Exposure } \\
(\mathbf{m S v})\end{array}$} & Lowest & Highest \\
\cline { 2 - 3 } & 0,00526 & 0,01666 \\
\hline Mean \pm SD & \multicolumn{2}{|c|}{$0,00885 \pm 0,00350$} \\
\hline
\end{tabular}

Tabel 2 showed that personal dose both lowest and highest dose was not exceed dose limited value (NBD) by Peraturan Kepala Badan Pengawas Tenaga Nuklir No. 4 Tahun 2013 NBD per 3 months is $5 \mathrm{mSv}^{[9]}$.

Monocyte count are measured by ADVIA 120/2120 tools with Differential Cell Count Method. The normal percentage of monocyte $2-8 \%$ of total leucocyte. Monocyte count in industrial radiography workers before and after working NDT activities can be seen in Table 3 .

Tabel 3. Monocyte Count in Industrial Radiography Workers at Before and After Working NDT Activities

\begin{tabular}{|l|r|r|r|r|}
\hline \multirow{2}{*}{$\begin{array}{c}\text { Monocyte Count } \\
(\%)\end{array}$} & \multicolumn{2}{|c|}{ Before Working } & \multicolumn{2}{c|}{ After Working } \\
\cline { 2 - 6 } & \multicolumn{1}{c|}{ n } & \multicolumn{1}{c|}{ n } & \multicolumn{1}{c|}{ \% } \\
\hline$<2$ & 0 & 0 & 0 & 0 \\
\hline $2-8$ & 10 & 90,91 & 11 & 100 \\
\hline$>8$ & 1 & 9,09 & 0 & 0 \\
\hline Mean \pm SD & \multicolumn{2}{|c|}{$5,59 \pm 1,39$} & $5,67 \pm 0,75$ \\
\hline
\end{tabular}

Monocyte count at berfore working for lowest count was 3,80\% and higest count was $8,80 \%$. Moreover monocyte count at after working for lowest count was 4,50\% and higest count was $6,80 \%$. Monocyte count in industrial radiography workers can be seen in figure 1. Based on statistical analysis with Paired Sample t Test showed t-value $(0,81)>0,05$ means there was no significant difference in monocyte count at before and after working NDT activities.

Serum level of IFN- $\gamma$ are measured by Human IFN- $\gamma$ Elisa Kit with ELISA Biotin Double Antibody Sandwitch Method. The normal level of IFN- $\gamma$ 0-188 pg/ml. Serum level of IFN- $\gamma$ in industrial radiography workers before and after working NDT activities can be seen in Table 4 .

Tabel 4. Serum Level of IFN- $\gamma$ in Industrial Radiography Workers at Before and After Working NDT Activities

\begin{tabular}{|c|c|c|c|c|}
\hline \multirow{2}{*}{$\begin{array}{c}\text { Serum Level of IFN- } \gamma \\
(\mathrm{pg} / \mathrm{ml})\end{array}$} & \multicolumn{2}{|c|}{ Before Working } & \multicolumn{2}{|c|}{ After Working } \\
\hline & $\mathbf{n}$ & $\%$ & $\mathbf{n}$ & $\%$ \\
\hline $0-188$ & 10 & 90,91 & 9 & 81,82 \\
\hline$>188$ & 1 & 9,09 & 2 & 18,18 \\
\hline $\begin{array}{l}\text { Mean } \pm \\
\text { SD }\end{array}$ & \multicolumn{2}{|c|}{$\begin{array}{r}88,98 \\
\pm 7.86\end{array}$} & \multicolumn{2}{|c|}{87,28} \\
\hline
\end{tabular}

Serum level of IFN- $\gamma$ at berfore working for lowest level was $39,35 \mathrm{pg} / \mathrm{ml}$ and higest level was $316,45 \mathrm{pg} / \mathrm{ml}$. Moreover serum level of IFN- $\gamma$ at after working for lowest level was $41,45 \mathrm{pg} / \mathrm{ml}$ and higest level was $284,90 \mathrm{pg} / \mathrm{ml}$. Serum level of IFN- $\gamma$ in industrial radiography workers can be seen in figure 2. Based on statistical analysis with Paired Sample t Test showed t-value $(0,29)>0,05$ means there was no significant difference in serum level of IFN- $\gamma$ at before and after working NDT activities.

Path analysis was showed that there is a significant correlation of gamma radiation exposure to decreased monocyte count (tvalue $2,25>1,96)$. Whereas gamma radiation exposure has no significant correlation to decreased serum level of IFN- $\gamma(\mathrm{t}-\mathrm{value}$ $0,18)$.

Monosit Pada Pekerja Radiografi Industri

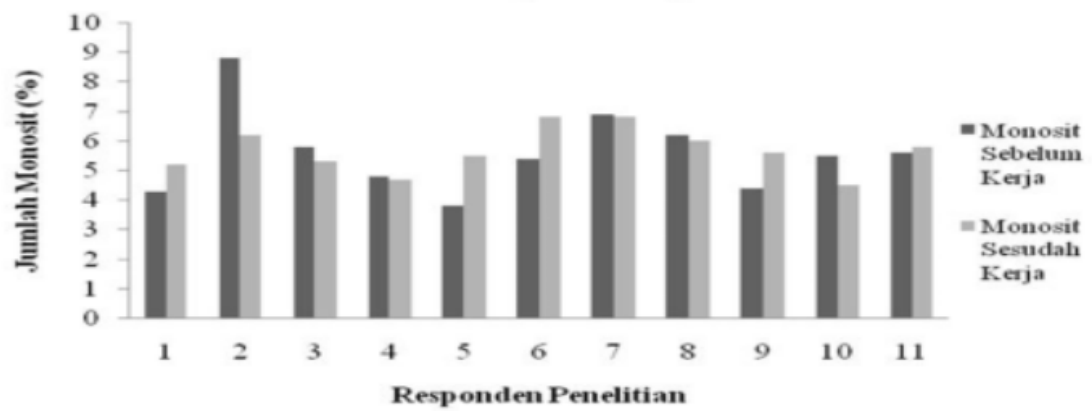

Fig 1. Tendency of Monocyte Count Distribution in Industrial Workers

\footnotetext{
${ }^{1}$ Niken Sekarningrum, Volume 4 Issue 08 August 2016 [www.ijsrm.in]
} 
DOI: $10.18535 / \mathrm{ijsrm} / \mathrm{v} 4 \mathrm{i8.08}$

Kadar IFN- $\gamma$ Serum Pada Pekerja Radiografi Industri

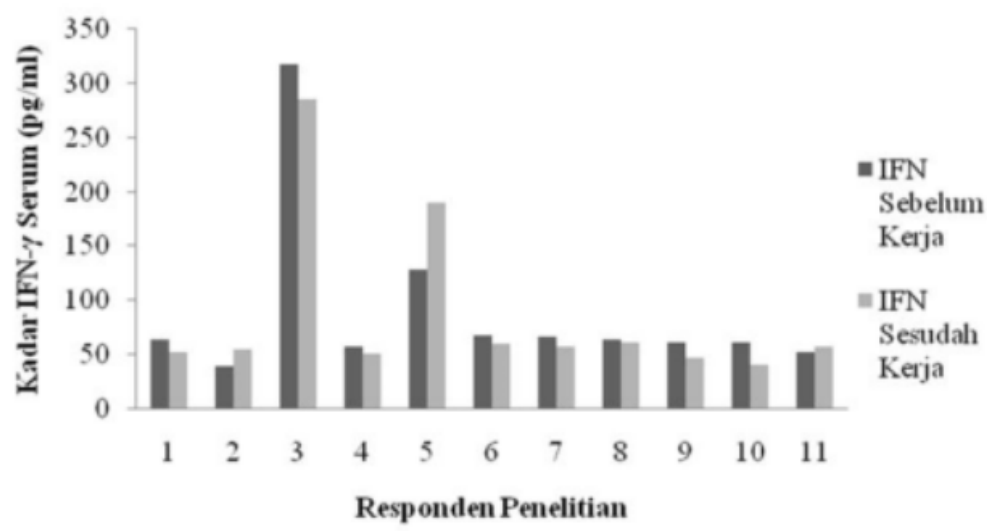

Fig 2. Tendency of Serum Level of IFN- $\gamma$ Distribution in Industrial Workers

Figure 1 showed that monocyte count in generally workers is at normal range 2-8\%. Figure 2 showed that serum level of IFN$\gamma$ in generally workers is at normal range $0-188 \mathrm{pg} / \mathrm{ml}$.

\section{DISCUSSION}

Distribution of monocyte count in this study has tendency to decrease after working NDT activities but based on path analysis there was no significant difference monocyte count before and after working in industrial radiography workers. Monocytes are immune system which respond to infection due to exposure to bacteria and foreign object. Monocyte respond slowly during the acute phase of infection and inflammation. Monocytes can lyse particles of foreign object larger ${ }^{[14]}$. Changes in monocytes become characteristic through inflammatory ${ }^{[13]}$.

This decline trend of monocyte count in accordance with theory that radiation exposure causes a change immune system. Blood cells can be decreased $60 \%$ compared with control group after being exposed to radiation at a dose $4 \mathrm{~Sv}^{[1]}$. But this decline trend of monocyte count different from preceding research showed that there was significant difference in monocyte count in the group of medical radiographer dirrectly contact with radiographer non dirrectly contact ${ }^{[15]}$. The absence of differences in monocyte count in industrial radiography workers due to monocyte count both before and after working NDT activities were still in normal range of monocytes. Whereas, this decline trend in accordance with the statement that radiation exposure can cause cell death or inhibited of mitotic stem cells activation. Inhibition of mitotic stem cells activation impact to decrease blood cells count. The decrease of monocyte impact to decrease the number of macrophage are known has function as phagocytosis, antigen presentation, enzym expression, and secretion of cytokines ${ }^{[3]}$.

Distribution serum level of IFN- $\gamma$ in this study has tendency to decrease after working NDT activities but based on path analysis there was no significant difference serum level of IFN- $\gamma$ before and after working in industrial radiography workers. This results was not based on theory that gamma radiation exposure is induce immunosuppresive and play a role in imbalance of cytokine expression of $\mathrm{T}$ helper $\mathrm{Th}) 1$ and $\mathrm{Th} 2{ }^{\left[{ }^{[6]}\right.}$. Pro-inflammatory cytokines is the component which is most react immediately and quickly during the cells being exposed to radiation ${ }^{[15]}$. IFN- $\gamma$ is a pro-inflammatory cytokine that is needed at the beginning of the inflammatory reaction in cellular immune response ${ }^{[4]}$. IFN- $\gamma$ also has a major function to activate macrophages. The presence of infammatory signals stimulate macrophage to bind into blood vessel, out of the blood vessels and move to the site of inflammation to kill target cells ${ }^{[1]}$. These cytokine levels will continue to be suppressed until foreign object can be eliminated ${ }^{[15]}$.

The absence of differences in serum level of IFN- $\gamma$ in industrial radiography workers due to serum level of IFN- $\gamma$ both before and after working NDT activities were still in normal range of serum level of IFN- $\gamma$.

Based on path analysis was showed that there was not a significant correlation of gamma radiation exposure to decreased serum level of IFN- $\gamma$. This results in accordance with the opinion that gamma radiation exposure may activate the phosphorylation path signal of STAT-1 (Signal Transducer and Activator of Transcription) for stimulate Concanavalin A, causing decrease IRF-1 (Interferon Regulatory Factor). Decrease of IRF-1 modulate to IFN- $\gamma$. This leads to decrease mRNA expression of IFN- $\gamma$ up to $40 \%{ }^{[6]}$. Uses of STAT pathway due to cytokine receptor for IFN- $\gamma$ deficiency during inflammation ${ }^{[15]}$. 


\section{DOI: $10.18535 / \mathrm{ijsrm} / \mathrm{v} 4 \mathrm{i8.08}$}

\section{CONCLUSION}

Gamma radiation exposure decrease of monocyte count significantly but not significant influence to decrease of serum level of IFN- $\gamma$ in industrial radiography workers.

\section{SUGGESTION}

Increase partisipation for refresh training every 5 years once (particularly for PPR) and other industrial radiography workers are advised to follow trainings about protection and radiation safety by accredited training institution. Moreover, its recommended to more improving health's workers especially ownership both medical history of infections and non infections disease through consuming of nutritious food (more low purine and fat) and water, doing sport regularly, and also doing enough rest.

\section{ACKNOWLEDGMENT}

Thanks to industrial radiografer in PT Spektra Megah Semesta and PT Andtech Surabaya which has been willing to became respondents in this study.

\section{REFERENCES}

[1] Alatas Z., 2001. Efek Radiasi Pada Komponen Seluler Sistem Imunitas Tubuh. Prosiding Seminar Nasional Keselamatan, Kesehatan, dan Lingkungan.

[2] Baratawidjaja KG. dan Rengganis I., 2010. Imunologi Dasar. Ed. 9. Jakarta : Balai Penerbit UI.

[3] Betz N., Ott OJ., Adamietz B., Sauer R., Fietkau R., and Keilholz L., 2010. Radiotheraphy in Early-Stage Dupuytren's Contracture : Long-Term Results After 13 Years. Strahlenther.Onkol., 186 (2) : 82-90.

[4] Goldsby RA., Kindt TJ., and Osborne BA., 2000. Kuby Immunology - Fourt Edition. California : Osborne and Associated. P 438.

[5] Han SK., Song YJ., Yun YS., and Yi SY., 2002. Gamma Irradiation-Reduced IFN- $\gamma$ Expression, STAT 1 Signals, and CellMediated Immunity. J.Biochem.Mol.Biol., 35 (6) : 583-589.

[6] ---, 2006. Effect of Gamma Radiation on Cytokine Expression and Cytokine-receptor Mediated STAT Activation. Int J.Radiat.Biol., 82 (9) : 686-697.

[7] Mayerni, Ahmad A., and Abidin Z., 2013. Dampak Radiasi Terhadap Kesehatan Pekerja Radiasi di RSUD Arifin Achmad, RS Santa Maria, dan RS Awal Bros Pekanbaru. JES, 7 (1) : 114-127.

[8] Minister of Law and Human Rights, 2007. Peraturan Pemerintah Republlik Indonesia No. 33 Tahun 2007 tentang Keselamatan Radiasi Pengion dan Keamanan Sumber Radioaktif.

[9] ---, 2013. Peraturan Kepala Badan Pengawas Tenaga Nuklir No. 4 Tahun 2013 tentang Proteksi dan Keselamatan Radiasi Dalam Pemanfaatan Tenaga Nuklir.

[10] Mukono, 2011. Prinsip Dasar Kesehatan Lingkungan. Ed 2. Surabaya : Airlangga University Press. P 153-156.

[11] Nabila AR., Montaal A., and Maguid AA., 2005. Effect of Fractionated and Single Doses Gamma Irradiation on Certain Mammalian Organs. EJHM, 19: 111-122.

[12] Pandey R., Shankar BS., Sharma D., and Sainis KB., 2005. Low Dose Radiation Induced Immunomodulation : Effect on Macrophage and CD8+ T Cells. Int.J.Radiat.Biol., 81 (11) : 801-812.

[13] Rodel F., Frey B., Manda K., Hildebrant G., Hehlgans S., Keilholz L., Seegenschmiedt MH., Gaipl US., and Rodel C., 2012. Immunomodulatory Properties and Molecular Effects in Inflammatory Diseases of Low-Dose X-Irradiation. Front.Oncol., 2 : 120.

[14] Sadikin M., 2001. Biokimia Darah. Jakarta : Widyakartika.

[15] Schaue D., Kachikwu EL., and McBride WH., 2012. Cytokines in Radiobiological Responses : A Review. Radiat.Res., 178 (6) : 505-523.

[16] Terubus, 2010. Komponen Sistem Hematopoitik Sebagai Bioindikator Tingkat Keterpaparan Radiasi Pada Pekerja/Operator Radiologi. Tesis. Universitas Airlangga. Surabaya.

[17] UNSCEAR, 2012. Biological Mechanisms of Radiation Actions at Low Doses - A White Paper to Guide the Scientific Committee's Future Programme of Work, New York : United Nations Scientific Committee on the Effects of Atomic Radiation.

[18] Wardhana WA., 2007. Teknologi Nuklir - Proteksi Radiasi dan Aplikasinya. Yogyakarta : ANDI. P 23-195.

\footnotetext{
${ }^{1}$ Niken Sekarningrum, Volume 4 Issue 08 August 2016 [www.ijsrm.in]
} 
Effects of Gamma Radiation Exposure to Reduce of Monocyte Count and Serum Level of IFN-y in Industrial Radiography Workers

ORIGINALITY REPORT

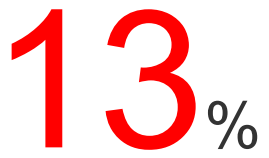

SIMILARITY INDEX
$9 \%$

INTERNET SOURCES
$7 \%$

PUBLICATIONS
$3 \%$

STUDENT PAPERS

PRIMARY SOURCES

1 ijsrm.in

Internet Source

2 Monika Paul-Samojedny, Aleksander Owczarek,

Renata Suchanek, Malgorzata Kowalczyk et al.

"Association Study of Interferon Gamma (IFN- $\gamma$ )

+874T/A Gene Polymorphism in Patients with

Paranoid Schizophrenia", Journal of Molecular

Neuroscience, 2010

Publication

3 repository.unair.ac.id

4 S. Stanilova, Z. Dobreva, Zh. Zhelev. "Changes in serum levels of cytokines in mice injected with an immunostimulator C3bgp isolated from

Cuscuta europea", International

Immunopharmacology, 2001

Publication 
6 ijptp.iomcworld.com

7 Submitted to Universitas Airlangga

Student Paper

8 WwW.icndt.org

9 Mohamed Labib Salem, Mohammad Sohrab Hossain. "Protective effect of black seed oil from Nigella sativa against murine cytomegalovirus infection", International Journal of Immunopharmacology, 2000

Publication

10 bioone.org Internet Source

11 docplayer.info Internet Source

12 www.freepatentsonline.com Internet Source

13 biologicalproceduresonline.biomedcentral.com Internet Source

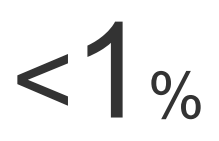


16 ijrat.org

I. P. Ivanova. "Induction of antiidiotypic immune response with autologous $\mathrm{T}$-cell vaccine in patients with multiple sclerosis", Bulletin of Experimental Biology and Medicine, 07/2008 Publication

18

Takashi Nishimura. "A pivotal role of IL-12 in $\mathrm{T}^{\mathrm{h}}$ 1-dependent mouse liver injury", International Immunology, 1996

Publication

Exclude quotes

Off

Exclude bibliography
Exclude matches

Off 


\section{Effects of Gamma Radiation Exposure to Reduce of Monocyte Count and Serum Level of IFN-y in Industrial Radiography Workers}

GRADEMARK REPORT

FINAL GRADE

10

PAGE 1

PAGE 2

PAGE 3

PAGE 4

PAGE 5
GENERAL COMMENTS

Instructor 